\title{
Reassessment of the corneal endothelial cell organisation in children
}

\author{
Andreas Müller, Michael J Doughty, Lesley Wright
}

\begin{abstract}
Aim-To assess uniformity of the corneal endothelial cell mosaic in children. Methods-36 healthy children (5-11 years old, 16 boys, 20 girls) were assessed by specular microscopy. Endothelial cell density (ECD) was calculated from measured cell areas, and the number of sides/cell noted.

Results-Average values for ECD and cell areas were 3987 cells $/ \mathrm{mm}^{2}(95 \%$ CI 3806 to 4168 cells $/ \mathrm{mm}^{2}$ ) and 278 (SD 85) $\mu^{2}$ respectively, with normal distribution (COV 28.2\%, range 17.4 to $39.2 \%$ ) and with the average percentage of six sided cells being $66.6 \%(8.8 \%)$. Cell area was positively correlated to number of cell sides (p $<0.01, r^{2}=0.993$ ), but the percentage of six sided cells was negatively correlated to ECD (p <0.01, $r=0.493)$.

Conclusion-A high ECD occurs in children, but this does not mean there is a high percentage of "hexagons".

(BrF Ophthalmol 2000;84:692-696)
\end{abstract}

The clinical specular microscope $e^{1-3}$ has been widely used on many different types of individuals with and without a range of eye diseases. ${ }^{4}$ It has become commonplace to assess endothelial cell density (ECD) and, perhaps the percentage of six sided cells ("hexagons"), particularly within the central corneal region. ${ }^{56}$ As part of ongoing studies to assess the corneal endothelium in more detail, ${ }^{58}$ further investigations were undertaken on children because reports on the corneal endothelium of children have been infrequent and the data differ somewhat. These studies confirmed that the corneal endothelium in children has a higher ECD than in young adults. ${ }^{5-20}$

The corneal endothelium has been considered to be essentially established as a uniform monolayer at some period shortly before birth, and then undergoes a progressive change with age that introduces non-uniformity into the monolayer. ${ }^{14}$ A key element of this uniformity is the presence, in relatively large numbers, of the six sided "hexagonal" cell, ${ }^{68}$ and it is likely that many would consider the corneal endothelium in children to be composed of a very high percentage of six sided cells. ${ }^{19}{ }^{15-17}$ In exploratory studies on a small group of children, a much higher than expected degree of nonuniformity within individual endothelia was encountered (unpublished results) even though the intersample variance in ECD was not substantial. These studies have thus been expanded and confirm that the endothelium of healthy white children can show quite a high degree of non-uniformity despite a high ECD, notably with respect to the percentage of six sided cells.

\section{Materials and methods}

The 36 subjects recruited were mainly children of members of staff (at Glasgow Caledonian University) and patients attending the university eye clinic. The protocol was approved by a departmental and university ethics committee. Informed written consent was provided by all parents. Based on responses to specific questions, all subjects were considered to have no major systemic disease and no history of significant eye disease or surgery. Fourteen of the children reported having had chickenpox, five had had measles, and one rubella (German measles), although no serological confirmation of these infections was sought in this study. Two children were reported to have an intermittent asthma history, but were not regularly using medications. The children were aged between 5 and 11 years of age (mean 8.3 years, median 8 years) with 16 boys and 20 girls. Only seven of the children were habitual spectacle wearers for mild to moderate refractive errors only (average spherical refractive error $=-0.125 \mathrm{D}$, range -2.75 to $+4.75 \mathrm{D}$ ).

A Topcon SP 1000 non-contact specular microscope was used to obtain a single micrograph of the central corneal endothelium of the left eye and which was analysed as previously detailed after a scale bar was affixed to the micrographs. ${ }^{58} \mathrm{~A}$ series of other measurements were taken on the same eye, or using both eyes (refractive error, visual acuity), which were designed to provide a general perspective on the cornea and eye of the children. Refractive error was measured with a Nikon NK5000 autorefractor. The anterior radius of curvature was averaged across the two principal meridians using a Javal-Schiotz type keratometer. Central corneal thickness (average of three measures) was measured by ultrasound pachymetry (Echopach pachymeter, 3M Canada Inc) after instillation of Minims Benoxinate $0.4 \%$ (oxybuprocaine, Chauvin), and a hand held non-contact tonometer (Keeler Pulsair 2000) was used for IOP measurement (average of three measures taken).

\section{Results}

The characteristics of the study group are summarised in Table 1 . None of the measures reveal anything remarkable about the set of children studied. A typical micrograph is shown in Figure 1. The average area sampled from each endothelium was $0.036 \mathrm{~mm}^{2}$ (range $0.025-0.048 \mathrm{~mm}^{2}$ ).
Accepted for publication 8 February 2000 
Table 1 Study group characteristics

\begin{tabular}{lll}
\hline Characteristic & Average value & Range of values \\
\hline Age & 8.3 & 5 to 11 \\
Refractive error & $-0.125 \mathrm{D}$ & -2.75 to $+4.75 \mathrm{D}$ \\
Central corneal thickness (SD) & $0.529(0.036) \mathrm{mm}$ & 0.441 to $0.605 \mathrm{~mm}$ \\
Anterior corneal curvature (SD) & $7.73(0.26) \mathrm{mm}$ & 7.05 to $8.35 \mathrm{~mm}$ \\
IOP (SD) & $15.4(2.4) \mathrm{mm} \mathrm{Hg}$ & 10 to $21 \mathrm{~mm} \mathrm{Hg}$ \\
\hline
\end{tabular}

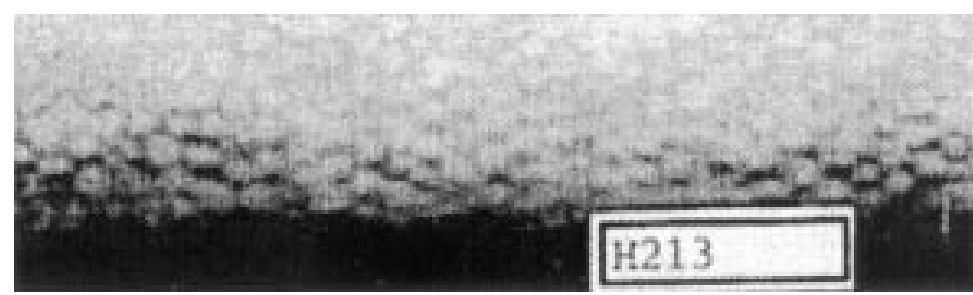

Figure 1 Typical non-contact specular micrograph of the corneal endothelium of a child. The ECD is 4050 cells $/ \mathrm{mm}^{2}$ compared with the group averaged value of $3987 \mathrm{cells} / \mathrm{mm}^{2}$ (see Results).
Analyses of the cell areas found within and across the set of 36 micrographs revealed average values for any particular endothelium to range from 208 to $396 \mu \mathrm{m}^{2}$ and a group averaged mean area value of $282 \mu \mathrm{m}^{2}$. Over the entire set of endothelial images, the cell areas ranged from 39 to $787 \mu \mathrm{m}^{2}$ and the overall median area was $275 \mu \mathrm{m}^{2}$ from the entire set of 4834 cells (which was almost identical to the group averaged median area of $280 \mu \mathrm{m}^{2}$ ). The distribution of cell areas is shown in Figure 2, both as pooled (A) and as group averaged histograms (B). These histograms indicate that there is little gross irregularity (polymegethism) in the endothelia analysed, as judged by the normal distribution of cell area values. The overall coefficient of skewness on the distribution averaged 0.409 (range -0.867 to 1.424 ) and the kurtosis averaged 0.904 (range -0.356 to 6.922 ). The normalised standard deviation of cell area values (the coefficient of variation, COV) is often used as a measure of uniformity, or non-uniformity, in the endothelial mosaic and these values averaged $28.2 \%$, range from 17.4 to $39.2 \%$. The endothelium depicted in Figure 1 is thus representative of the overall average data from the set of 36 children in that its ECD was 4050 cells $/ \mathrm{mm}^{2}$, the average cell area was $275 \mu \mathrm{m}^{2}$ (median $285 \mu \mathrm{m}^{2}$ ) and its COV was $28.6 \%$. A more detailed evaluation of the composition of the samples of endothelial mosaic provides a rather different perspective however.

The overlay generated from the micrograph of Figure 1 is shown in Figure 3. The six sided cells are indicated and comprised 80 of 131 cells in this example - that is, $61.0 \%$. Overall, the 36 endothelial samples contained an average of $66.6 \%$ (SD $8.8 \%$ ) six sided cells, with these cells having an average area of 285 (34) $\mu \mathrm{m}^{2}$. Similar proportions of five sided and

Table 2 Summary of corneal endothelial studies in children

\begin{tabular}{|c|c|c|c|c|c|}
\hline $\operatorname{Ref} N o$ & Year & Age of children & $E C D\left(\mathrm{cells} / \mathrm{mm}^{2}\right)$ & $\begin{array}{l}\text { Range of ECD } \\
\text { values }\left(\text { cells } / \mathrm{mm}^{2}\right)\end{array}$ & $\begin{array}{l}\text { Percentage six sided cells } \\
\text { ("\% hexagons") }\end{array}$ \\
\hline \multicolumn{6}{|l|}{ Infants } \\
\hline 14 & 1986 & $3-21$ days & 6100 & & \\
\hline 15 & 1987 & $<12$ months & 4425 & $3450-5600$ & \\
\hline 16 & 1988 & $<12$ months & 4252 & $3000-5700$ & \\
\hline 36 & 1989 & $<12$ months & 4291 & $3547-5305$ & $82(4.5)(\mathrm{X}(\mathrm{SD}))$ \\
\hline 19 & 1992 & $>5$ weeks & 5200 & $3800-5700$ & \\
\hline \multicolumn{6}{|l|}{ Children } \\
\hline 9 & 1976 & 6 years (case) & 3015 & & \\
\hline 1 & 1976 & $6-11$ years & 3150 & $2950-3250$ & \\
\hline 10 & 1978 & $3-11$ years & $4300^{\star}$ & & \\
\hline 11 & 1979 & $5-9$ years & 2681 & $1640-3869$ & \\
\hline 30 & 1979 & $3-6$ years & 3750 & $3000-4000$ & \\
\hline 35 & 1980 & $0-10$ years & 4000 & & \\
\hline 31 & 1981 & $11-16$ years & 3080 & $2247-3769$ & \\
\hline 3 & 1982 & $0-9$ years & 3470 & & \\
\hline 25 & 1984 & $0-10$ years & no ECD & & 73-75† \\
\hline 33 & 1985 & 2 years (mean) & 3100 & & \\
\hline 34 & 1987 & 3 months -14 years & 3001 & $2300-3700$ & \\
\hline 15 & 1987 & $4-12$ years & 3268 & $2658-3638$ & \\
\hline 26 & 1988 & $5-10$ years & no ECD & & $80-85+$ \\
\hline 36 & 1989 & $5-11$ years & 3581 & $3067-4171$ & $82(5.5)(\mathrm{X}(\mathrm{SD}))$ \\
\hline 17 & 1990 & $5-14$ years & 3160 & $2597-3981$ & \\
\hline 19 & 1992 & $0-5$ years & $4800 \ddagger$ & $3800-5800$ & \\
\hline 29 & 1992 & $<10$ years & 3491 & & $88.4(4.5)(\mathrm{X}(\mathrm{SD}))$ \\
\hline 20 & 1997 & 6 months -10 years & $4600 \ddagger$ & $3400-4750$ & \\
\hline 5 & 1999 & $6-10$ years & 4126 & $3349-5316$ & \\
\hline This study & 1999 & $5-11$ years & 3987 & $2627-5316$ & $66.6(8.8)(\mathrm{X}(\mathrm{SD}))$ \\
\hline
\end{tabular}

^These ECD estimates were obtained by using the authors' own scaling factor $(\times 210)$ to change counts/cornea into cells $/ \mathrm{mm}^{2}$. †From regression analysis.

$\ddagger$ Postmortem, histological study. 

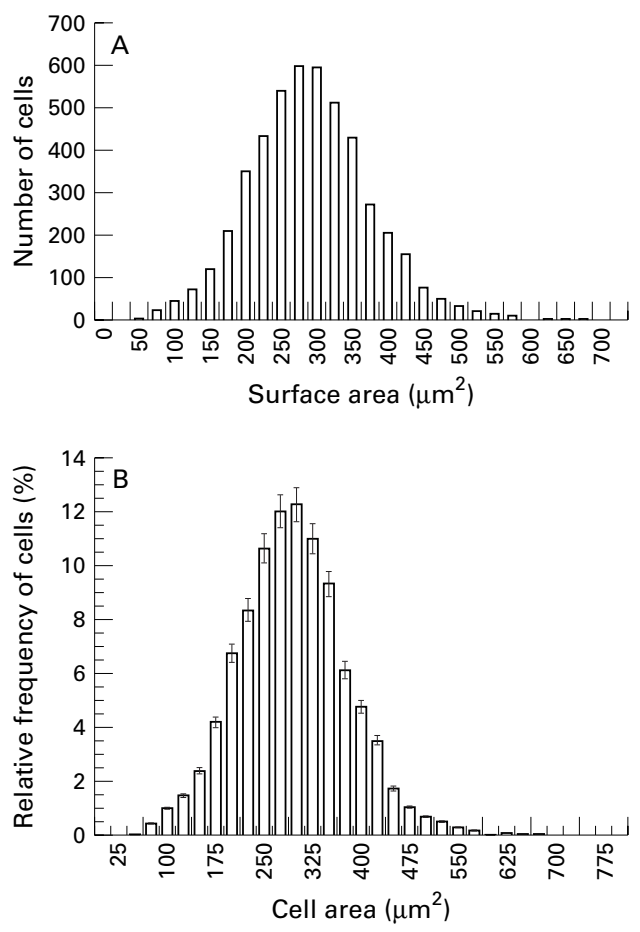

Figure 2 Group averaged histogram of endothelial cell areas. The area values were grouped into 0-25, 26-50, etc. and the entire data set pooled $(A)$ or the average values within each group calculated and the mean (SEM) for each interval presented (B). In either case, the overall distribution of areas is clearly Gaussian.

seven sides cells were present in all the endothelia (that is, $15.2 \%(3.9 \%)$ and $14.6 \%$ $(3.7 \%)$ respectively) with their average areas being 202 (31) $\mu^{2}$ and 356 (44) $\mu \mathrm{m}^{2}$. Most of the endothelia (27 of 36 ) also contained at least one four sided cell (average $1.9 \%(1.4 \%)$ of the cells assessed), while 26 of 36 endothelia contained at least one eight sided cell (average $1.8 \%(1.0 \%))$. The average area of the four sided cells was very small (at $94(21) \mu \mathrm{m}^{2}$ ) while the eight sided cells were much larger (442 (99) $\mu \mathrm{m}^{2}$ ). Only two endothelia contained a solitary nine sided cell (average area 608 $\mu \mathrm{m}^{2}$ ). The relation between the cell areas, with respect to the number of sides from four to eight inclusive, was linear (Fig 4). A linear regression analysis across the group averaged mean cell areas for each cell type (Fig 4A) was highly significant $\left(\mathrm{p}<0.01 ; r^{2}=0.993 ; 4 \mathrm{dF}, \mathrm{F}\right.$ ratio=543). The average area of the nine sided cells (at $441 \mu \mathrm{m}^{2}$ ) also fits on the same regression line. A Kruskal-Wallis analysis across the sets of average cell area values (Fig $4 \mathrm{~B})$ was also highly significant $\left(\chi^{2}=142,4 \mathrm{dF}\right.$, $\mathrm{p}<0.01)$. Further analyses also revealed that the relation between the percentage six sided cells and the ECD was similarly significant ( $p$ $<0.01$ ), but with a substantial negative correlation (Fig 5). A linear regression analysis yielded a Pearson correlation coefficient of $r=$ $0.492(p<0.01, F$ ratio $=10.92)$. Plots of the coefficient of skewness, on the cell area distributions for any one endothelial micrograph, against either ECD or the percentage six sided cells in the micrograph revealed no significant correlations $(p>0.2)$. Such a lack of correlation confirms that the set of endothelial

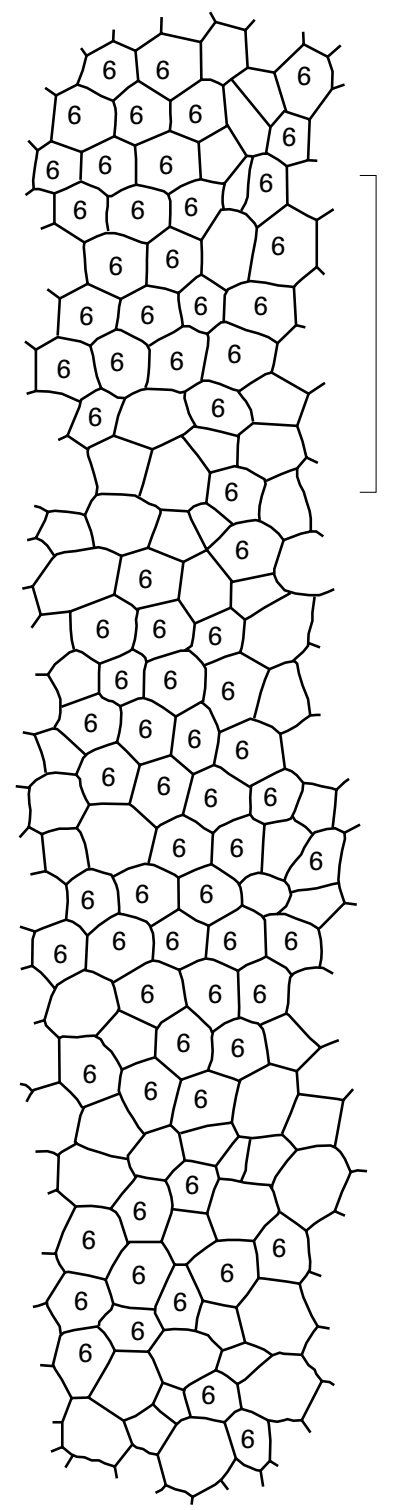

Figure 3 Tracing overlay of the endothelial mosaic from Figure 1. The six sided cells are so indicated with the overall percentage of six sided cells being $61 \%$, compared with the group averaged value of $66.6 \%$ (see Results). Bar $=0.05$ $\mathrm{mm}$.

samples examined were relatively uniform and that the negative correlation between ECD and percentage six sided cells was not due to mosaic samples with a skewed cell distribution (that is, outlier effects).

\section{Discussion}

The corneal endothelial monolayer, when fully developed, is considered vitally important for maintaining corneal clarity. ${ }^{22}$ It has still however to be quantitatively established in what way the organisation of the corneal endothelial mosaic is related to its function. ${ }^{4823} \mathrm{~A}$ decrease in cellularity and increase of the corneal surface to be covered results in changes in endothelial cell organisation, size, shape, and thickness and, by the eighth month, the endothelial cells are considered to be active and fully functional. ${ }^{13} 24$ High ECD values $\left(>4200\right.$ cells $\left./ \mathrm{mm}^{2}\right)$ have been reported just after birth or in infancy (Table 2). 

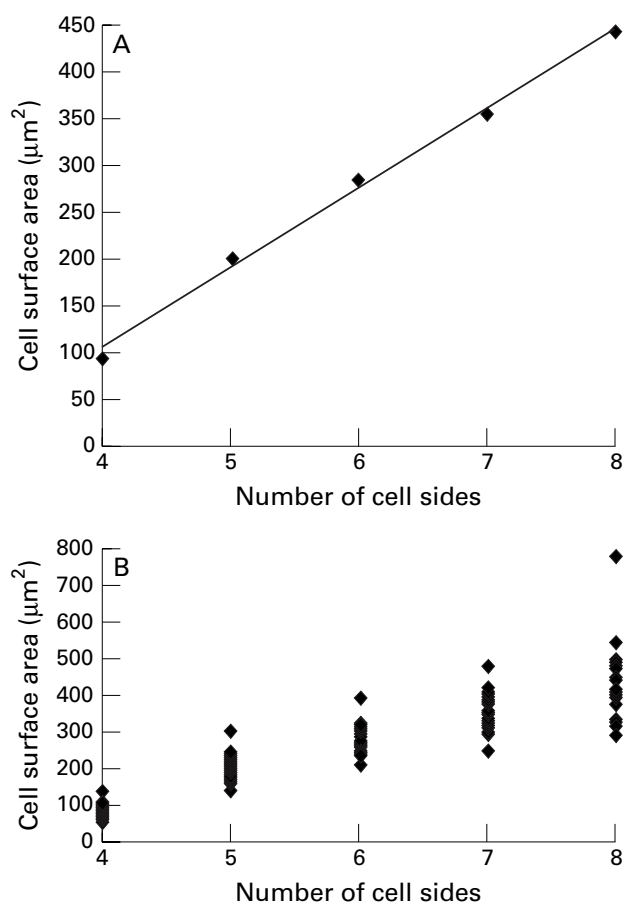

Figure 4 Area side relations for corneal endothelial cells. The group averaged mean value for the area of each cell type (four, five, six sided, etc) is plotted against the number of cell sides $(A)$ or the mean values from each data set shown in the scatter plot $(B)$. The linear regression shown in $(A)$ is statistically significant $\left(p<0.01 ; r^{2}\right.$ value of $0.993)$, while the $\chi^{2}$ value across groups in (B) is highly significant at $142(4 \mathrm{dF}, p<0.01)$.

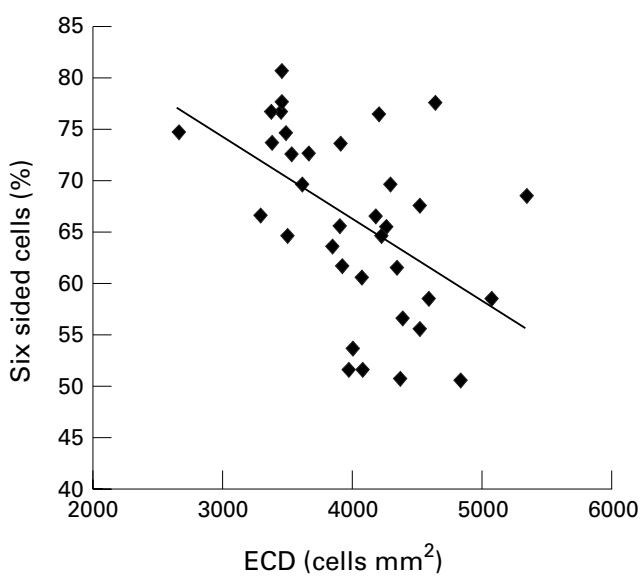

Figure 5 Relation between ECD and the percentage of six sided cells in the endothelium. The linear regression is statistically significant $(p<0.01 ; r=0.492)$.

Thereafter, ECD values have been reported to be lower (Table 2), although the kinetics of the change in ECD with time have yet to be well defined-for example, as a linear or logarithmic function. ${ }^{5}$

The present studies reveal an unexpected extent of non-uniformity in cell shape (pleomorphism) in the endothelia of normal healthy children. As noted earlier, some consider the corneal endothelium in children to be composed of a very high percentage of six sided cells, ${ }^{19}{ }^{15-17}$ but there are few published data to support such an idea. There have certainly been quite a few studies on the corneal endothelia in children, ${ }^{5-20}$ 25-36 but few details on the actual number of six sided cells (the "hexagons") in these endothelia have been published (see Table 2). A number of investigators have presented data to indicate that the percentage of hexagons decreases as a function of age ${ }^{25-27} \mathrm{Kim}$ et $a l^{29}$ report that children aged $<10$ years had $88 \%$ hexagons, while an average value of $82 \%$ was reported by Tusukahara et $a l^{36}$; both studies are, however, on non-white eyes. Others have provided regression analysis of age dependent changes from which the percentage of hexagons could perhaps be estimated-for example, the regression analyses reported Carlson et $a l^{26}$ would yield a value of around $82 \%$ for 5-10 year olds, while a study by Suda, ${ }^{25}$ would yield an estimate of $73-75 \%$. A range of values for the percentage of six sided cells in children has thus been reported, and such a range is important to note. Some studies would be consistent with a concept that children's endothelia are regular in appearance, and include a very high percentage of hexagons. ${ }^{962936}$ Other reports have simply commented that the corneal endothelia in newborn (human) are very homogeneous with respect to cell size and form. ${ }^{16}{ }^{28}$ However, others have considered that the corneal endothelia in any very young individuals (including human) should contain cells that were smaller and more pleomorphic compared with those in adults (although specific data for human endothelia were not provided). ${ }^{14}$ Such an early life pleomorphic appearance is especially remarkable for feline endothelia. $^{37}$

The consistent finding of subtle nonuniformity in the endothelia of apparently healthy young children suggests therefore that this is a normal attribute of these endothelia and that a further reorganisation has yet to occur to realise the highest values for percentage hexagons (and after which an age dependent decline could then occur). A fairly wide range of ECD values were found (2627-5316 cells $/ \mathrm{mm}^{2}$ ) and it is readily acknowledged that there are a variety of factors that might be responsible for the differences. Such factors could include eye size, refractive error, corneal curvature, and corneal thickness. For example, an analysis of the possible relation between horizontal corneal diameter reveals a negative correlation that just reaches statistical significance $\left(\mathrm{p}=0.05, \mathrm{~F}\right.$ ratio $\left.=4.111, r^{2}=0.332\right)$. Further and more extensive studies are thus currently in progress to try to establish which, if any, of these factors might play the most important role in determining the uniformity of the corneal endothelium in children.

1 Bourne W, Kaufman H. Specular microscopy of human corneal endothelium in vivo. Am $f$ Ophthalmol 1976;81:319-23.

2 Bourne WM, Enoch JM. Some optical principles of the clinical specular microscope. Invest Ophthalmol 1976;15: 29-32.

3 Bigar F. Specular microscopy of the corneal endothelium. Dev Ophthalmol 1982;6:1-94.

4 Doughty MJ. Toward a quantitative analysis of corneal endothelial cell morphology: a review of techniques and their application. Optom Vis Sci 1989;66:626-42.

5 Doughty MJ, Müller A, Zaman ML. Assessment of the reliability of corneal cell density estimates using a non-contact ability of corneal cell density estimates using a non

6 Doughty MJ. Concerning the symmetry of the "hexagonal" cells of the corneal endothelium. Exp Eye Res 1992;55:14554 . 
7 Doughty MJ. Prevalence of 'non-hexagonal' cells in the corneal endothelium of young caucasian adults, and 22 .

8 Doughty MJ. Are there geometric determinants of cell area in rabbit and human corneal endothelial cell monolayers. Tissue Cell 1998;30:537-44.

9 Bourne W, Kaufman H. The endothelium of clear corneal transplants. Arch Ophthalmol 1976;94:1730-2.

10 Laule A, Cable MK, Hoffman CE, et al. Endothelial cell population changes of human cornea during life. Arch Ophthalmol 1978;96:2031-5.

11 Hiles DA, Biglan AW, Fetherolf EC. Central corneal endothelial cell counts in children. Am Intra-Ocular Implant Soc F 1979;5:292-300.

12 Stefansson A, Müller O, Sundmacher R. Non-contact specular microscopy of the normal corneal endothelium. A
statistical evaluation of morphometric parameters. Graefes Arch Clin Exp Ophthalmol 1982;218:200-5.

13 Murphy C, Alvarado J, Juster R, et al. Prenatal and postnatal cellularity of the human corneal endothelium. Invest cellularity of the human corneal
Ophthalmol Vis Sci 1984;25:312-22.

14 Bahn C, Glassman RM, MacCallum DK, et al. Postnatal development of corneal endothelium. Invest Ophthalmol Vis Sci 1986;27:44-51

15 Sherrard ES, Novakovic P, Speedwell L. Age-related changes of the corneal endothelium and stroma as seen in vivo by specular microscopy. Eye 1987;1:197-203

16 Speedwell L, Novakovic P, Sherrard ES, et al. The infant corneal endothelium. Arch Ophthalmol 1988;106:771-5.

17 Nucci P, Brancato R, Mets M, et al. Normal endothelial cell density range in childhood. Arch Ophthalmol 1990;108 $247-8$

18 Daus W, Völcker HE. Hornhautendothel. Anatomie, Physiologie, Biomikroskopie, Klinik und Pathologie. Ophthalmologe 1992;89:W15-26.

19 Williams KK, Noe RL, Grossniklaus HE, et al. Correlation of histologic corneal endothelial cell counts with specular microscopic density. Arch Ophthalmol 1992;110:1146-9.

20 Möller-Pedersen, T. A comparative study of human corneal keratocyte and endothelial cell density during ageing. Corkeratocyte and endot

21 Waring GO, Bourne WM, Edelhauser HF, et al. The corneal endothelium. Normal and pathologic structure and function. Ophthalmology 1982;89:531-90.
22 Hartmann C, Kolb M, Knauer I. Klinische Spiegelmikroskopie. Technik, Organisation und einfache Kleinrechner-Morphometrie. Klin Monatsbl Augenheilkd 1983,186:96-104.

23 Blatt HL, Rao GN, Aquavella JV. Endothelial cell density in relation to morphology. Invest Ophthalmol Vis Sci 1979;18 $856-9$

24 Wülle K. Electron microscopy of the foetal development of the corneal endothelium and Desçemet's membrane of the human eye. Invest Ophthalmol 1972;11:897-904.

25 Suda T. Mosaic pattern changes in human corneal endothelium with age. fpn f Ophthalmol 1984;28:331-8.

26 Carlson $\mathrm{KH}$, Bourne WM, McLaren JW, et al. Variations in human corneal endothelial cell morphology and permeability to fluorescein with age. Exp Eye Res 1988;47:27-41.

27 Matsuda M, Shiozaki Y, Suda T, et al. Chronological change of human corneal endothelial cell shape and its arrangement [in Japanese]. Acta Soc Opthalmol fpn 1982;86:1944-51.

28 Schimmelpfennig B. Topographie altersbedingter Grössenveränderungen von Kornea-Endothelzellen. Klin Montasbl Augenheilkd 1984;184:353-6.

29 Kim KS, Park SY, Oh JS. Morphometric analysis of the corneal endothelial cells in normal Korean [in Korean]. $\mathcal{f}$ Korean Ophthaluol Soc 1992:33.24-9.

30 McCarey BE. Noncontact specular microscopy: a macrophotography technique and some endothelial cell findings. Ophthalmology 1979;86:1848-60.

31 Price NC, Barbour DJ. Corneal endothelial density in twins. Br F Ophthalmol 1981;65:812-14.

32 Bigar F. Specular microscopy of the corneal endothelium. Dev Ophthalmol 1982;6:1-94.

33 Hoskovcova-Kreicova H, Hoskovec P, Krejci L, et al. Klasifikace endotelialnich nalezu u kongenitalniho glaukomu piocitacovou. Cesk Oftalmol 1985;41:252-7.

34 Egorova EV, Zubareva LN, Vilshanskaja OE, et al. Corneal endothelium in children with lens pathology [in Russian]. Vestn Oftalmol 1987;103:43-5.

35 Hoffer KJ, Kraff MC. Normal endothelial cell count range. Ophthalmology 1980;87:861-6.

36 Tsukahara Y, Yamamoto M. Postnatal development of corneal endothelial cells in normal children. Acta Soc Ophthalmol fpn 1989;93:763-8.

37 Chan-Ling T, Curmi J. Changes in corneal endothelial morphology in cats as a function of age. Curr Eye Res 1988;7:387-92. 